\title{
PRINCIPLES OF LIVESTOCK DEVELOPMENT IN THE REPUBLIC OF SERBIA
}

\author{
M. P. Petrović ${ }^{1}$, M. M. Petrović ${ }^{1}$, V. Caro Petrović ${ }^{1}$, D. Ružić Muslić ${ }^{1}$, \\ Z. Ilić ${ }^{2}$, M. Petrović ${ }^{3}$, Z. Pavlovski \\ ${ }^{1}$ Institute For Animal Husbandry, Belgrade, Serbia \\ ${ }^{2}$ University of Pristina, Faculty of Agriculture, Kopaonicka bb, 38219 Lesak, Serbia \\ ${ }^{3}$ Faculty of Agriculture, University of Belgrade, 11080, Belgrade - Zemun, Repulic of Serbia \\ Corresponding author: milanppet@yahoo.com
}

\begin{abstract}
Livestock production is an important branch of agriculture in the Republic of Serbia because it provides necessary products (milk, meat, eggs). In addition, livestock production provides raw materials for food industry and leather industry. Livestock production is expected to provide quality products for export, primarily beef and lamb. There is an opportunity for export of cheese (especially sheep and goat milk cheese) with defined origin and standard of quality. However, based on available data, the situation in livestock production is assessed as negative. In the last years, number of heads of all species of domestic animals has decreased continuously. In several years, Serbia will become member of European Union (EU). This means that livestock production should prepare for competition in the single developed market, without any state trade barriers. Serbia's membership in international organizations, liberalization of trade in livestock products, a small possibility of protection from imports, the implementation of quality standards (HACCP, ISO, Global GAP), reduced levels of domestic support, elimination of export subsidies, increase profitability and ability to be competitive on the international market. Based on these circumstances, it is necessary to build efficient livestock production that can compete in the European market contributing to the growth of farmers and national income.
\end{abstract}

Keywords: livestock production, new technologies, agricultural policy

\section{Introduction}

Livestock in Serbia is facing serious challenges as a result of transition and development of new applications in food production. Animal science has a great contribution in the realization of efficient livestock production. Many opportunities 
are open to the animal breeding and reproduction sector for improving the biological and economic efficiency of food production and increasing food supply. Serbia is situated in the middle of the Balkan Peninsula and has an area of around 88.360 square kilometers. In the total area of Serbia, which is around 8.800.000 ha, the agricultural area covers around 5.100.000 ha, out of which $83 \%$ - that is around 4.250.000 ha - is cultivable. In Serbia, farmers constitut $17.3 \%$ of the total population. The distribution of the population working in farms in Serbia ore as follows: animal production $43 \%$, crop production $42 \%$, production of vine and grapevine 12\%, and other crops 3\% (Bogdanovic et al, 2005, Petrovic et al, 2006). Serbia has considerable nature resources (agricultural land, climate, water and vegetable etc.) and very significant capacities and potentials (farmers, livestock fund, production and processing structures and techniques, etc.). The Republic of Serbia has 5.1 million ha of agricultural land, 4.2 million ha of arable land and fields and 0.83 million ha grassland, approx. 0.6 ha of agricultural and 0.5 ha of arable land per capita. The quality of soil is best in low lands and moderately good in hilly and mountain regions (Petrovic et al, 2002, Aleksic et al, 2007).

\section{Livestock Production in Serbia}

Serbia has a long tradition in livestock production. Livestock is the most important branch of agriculture in the country, present in more than 700,000 households ( $55 \%$ of total households). Livestock production provides the necessary products (milk, meat, eggs) to feed the local population. In addition, livestock production provides raw materials for food industry (dairies, slaughterhouses, confectionery and leather industry). Livestock production is expected to provide quality products for export, primarily beef and lamb (Petrovic, 2007). There is an opportunity for export of cheese (especially sheep and goat milk cheese) with defined origin and standard of quality. However, during the last decades, livestock breeding in Serbia has been facing numerous problems, especially the problem of small farms and the small number of animals on the farms (Petrovic et al., 2005, Ivanovic et al., 2009). The average farm size is around 3 ha, divided into several parts, as a result of numerous agricultural policies in the past. As regards the property of land, $87 \%$ of land is private property, while the rest is of state property. Based on available data, the situation in livestock production is assessed as negative. The number of heads of all species of domestic animals and poultry in the last ten years (2000-2011) has decreased continuously (table 1). 
Table 1. The number of heads of all species of domestic animals ( 000 heads)

\begin{tabular}{|c|c|c|c|c|c|}
\hline Year & Cattle & Pig & Sheep & Goat & Poultry \\
\hline 2000. & 1.246 & 4.066 & 1.611 & 183 & 20.360 \\
\hline 2006. & 1.106 & 3.999 & 1.556 & 162 & 16.595 \\
\hline 2007. & 1.087 & 3.832 & 1.606 & 149 & 16.422 \\
\hline 2008. & 1.057 & 3.594 & 1.605 & 154 & 17.188 \\
\hline 2009. & 1.002 & 3.631 & 1.504 & 143 & 22.821 \\
\hline 2010. & 938 & 3.489 & 1.475 & 128 & 20.156 \\
\hline 2011 & 936 & 3.286 & 1.460 & 129 & 19.103 \\
\hline
\end{tabular}

The number of cattle decreased by $24 \%$, pigs by $14 \%$, sheep by $8 \%$, and goats by $30 \%$. According to new data of December 2011, compared to 2010, the total number of cattle decreased by $0.2 \%$, pigs for $5.8 \%, 1.0 \%$ for sheep, and poultry by $5.2 \%$, while the number of goats increased by $0.8 \%$.

Meat production per animal species is presented in table 2 .

Table 2. Meat production per animal species (000 tons)

\begin{tabular}{|c|c|c|c|c|c|}
\hline Year & Beef meat & Sheep meat & Pig meat & Poultry meat & Total \\
\hline 1990. & 139 & 23 & 282 & 104 & 548 \\
\hline 2000. & 104 & 19 & 283 & 67 & 473 \\
\hline 2005. & 90 & 21 & 253 & 67 & 431 \\
\hline 2007. & 95 & 20 & 289 & 70 & 474 \\
\hline 2008. & 99 & 23 & 266 & 76 & 464 \\
\hline 2009. & 100 & 25 & 252 & 80 & 457 \\
\hline 2010. & 92 & 23 & 269 & 84 & 468 \\
\hline 2011. & 81 & 24 & 271 & 103 & 479 \\
\hline
\end{tabular}

Table 2 shows that Serbia produces 81,000 tons of beef, 271,000 tons of pork, 24,000 tons of sheep meat and 103,000 tons of poultry meat. Total meat production in the Republic of Serbia has a tendency of stagnation or slight decline. Dominated pork meat production with the participation of $56.57 \%$ of total production, beef takes $16.90 \%$, poultry and sheep $26.51 \%$. 
Table 3. Milk production in Serbia

\begin{tabular}{|c|c|c|}
\hline Year & Cow's milk (million liters) & Sheep milk(million liters) \\
\hline 1990. & 1.805 & 20 \\
\hline 2000. & 1.585 & 19 \\
\hline 2005. & 1.602 & 16 \\
\hline 2006. & 1.587 & 14 \\
\hline 2007. & 1.549 & 14 \\
\hline 2008. & 1.534 & 10 \\
\hline 2009. & 1.478 & 9 \\
\hline 2010. & 1.462 & 11 \\
\hline 2011. & 1.434 & \\
\hline
\end{tabular}

From table 3 it is obvious that the production of cow's milk decreased by $20.55 \%$ and sheep milk by $45 \%$. This is a consequence of reducing the number of cows and sheep, as we have seen in Table 1. The consumption of cow's milk in Serbia is 56 liters per capita and less than the average consumption in the EU where the average of 86 liters. Sheep milk is used for the production of quality cheeses.

\section{Measures for Livestock Development}

\section{Increased competitiveness}

To build efficient Livestock Production that can compete in the global market contributing to the growth of national income. Competitiveness is the concept of comparing skills and performance of the company, sector or country to sell and supply goods and / or services in a given market. Livestock of the Republic of Serbia is faced with many problems that are primarily the result of low capital investment, resulting in relatively low competitiveness and lagging behind comparable countries. There are registration and individuals who have their products competitive, as competition builds on the use of abilities, skills and creativity of individuals to adapt to new conditions. New conditions for agriculture of the Republic of Serbia shall be established and reflected in the transition from centrally planned economies, where the greatest responsibility on the state apparatus, to a market where the center of the responsibility of the individual. The new integration processes (the WTO and the EU) will further change the economic conditions that will be reflected in the liberalization of agriculture, and therefore require even greater competitiveness. Increasing competitiveness is reflected in rising living standards over time and it can increase investment both in equipment 
and new technologies and investments in knowledge. It was noted that the situation in livestock must be improved and that the structure of farms, quality standards, marketing, education and training. Only by increasing the competitiveness of farmers from the Republic of Serbia can not survive and thrive in the highly competitive EU internal market.

\section{Food quality}

To provide food that meets the needs of consumers in terms of safety and quality. This achievement should lead to increased consumer safety, higher profitability and competitiveness of the food industry, increase exports by filling out the request of the importer countries, replacement of imported items in the same level of national security, reduce cost control, and therefore cheaper to manufacture, provision of international integration (membership in the EU and WTO). Building a comprehensive, coordinated and integrated national disease surveillance system of animals is the basis of preserving the health of animals, humans and the environment, and food production. The biggest effort in achieving this goal lies with the institutions that their action through the establishment of legislation and capacity building inspection services should lead to the fact that food is completely safe. Various structural measures in order to support investments in modern facilities that provide a greater degree of food safety and the introduction of standards can support the achievement of this goal.

\section{Standard support}

Provide support to the living standard of people who depend on livestock, and are not able to follow economic reform. The specificity of agriculture is that apart from production to market needs a certain amount of production used for own purposes (consumption on the farm). Some farms are market oriented and can not be competitive either because of their personal capacity or because they are located in areas less suitable for livestock production. To this category belongs mostly older population living on pensions and / or rental of land, while the production intended for their own needs. It is important to define policies that will be directed toward supporting the income of those categories that produce for their own purposes and are not able to be competitive in the market. Most appropriate classification of farms according to their market orientation is a division of farms into commercial and noncommercial.

\section{Rural Development}

Provide support to sustainable rural development encompasses a much broader area of understanding of agriculture. Rural development policy is a set of different socio-economic activities defined rural policy aimed at rural areas. Essentially, these are activities related to improving the lives and economic activity in rural areas, and often include investments in funds for agricultural production and processing, construction and rehabilitation of rural infrastructure, education and training of rural people, improvement of rural tourism, promoting traditional and cultural values, protection natural environment and surroundings. The main 
problems for a long delay in the development of rural areas are related to the migration of rural population to urban areas, unfavorable age structure, insufficient investment in rural development and rural life, where they are neglecting other activities that contribute to its development, facilities, infrastructure, rural tourism and the like. It is necessary to pay special attention to the fact that different regional areas are at different levels of rural development and as such require different systems of support measures.

\section{New technologies application}

It is necessary to improve the production potential of certain species and breeds of domestic animals using genetic-selection measures. Beside standard selection methods, today methods of molecular genetic are used more and more. All this knowledge should be used when developing breeding programs. By application of new technologies in livestock production and processing a higher level of production and improved quality of livestock products will be ensured. By introduction of new technologies the efficiency and competitiveness of this production will be improved on the global market

\section{Protection of environment}

To preserve the environment from the adverse effects of livestock production, environmental protection policy is implemented through organic agriculture programs, and for which the current interest in the Republic of Serbia is very low. Long-term goal of Serbia is to become a member of the EU and to this end it is necessary to set new and harmonize existing standards with EU policy, as well as define the main directions of environmental policy, particularly specifically defined for agricultural areas.

\section{Conclusion}

Contribution of livestock production in production structure of agriculture indicates the level of development of agricultural production of one country. In the structure of gross realized value, share of plant production in Serbia is $58 \%$, and of livestock production only $42 \%$. In agriculture of EU countries, approx. $70 \%$ of value originates from livestock production, and 30\% from plant production. Official data show that the numbers of almost all livestock decreased during the period 2000-2011.

The total meat production in Serbia shows a tendency of slight decrease, except for sheep and poultry meat.

Production of cow milk in 2011 amounted to 1.434 mil. liters and sheep milk 11 mil. liters. Carriers of this production are family households which provide $92 \%$ of total production. The Dairy plants purchase off approx. 400 million liters of milk annually ( $30 \%$ of the raw milk).

Long term implementation of recommended measures should stop further decrease of number of livestock, provide increase of profitability and competitiveness of livestock production and improve the quality of livestock 
products, which is important as crucial factor of future development of sustainable livestock production in Serbia.

\section{Principi razvoja stočarstva u Republici Srbiji}

M.P. Petrović, M. M. Petrović, V. Caro Petrović, D. Ružić Muslić, Z. Ilić, M. Petrović, Z. Pavlovski

\section{Rezime}

Stočarska proizvodnja je važna grana poljoprivrede u Republici Srbiji i posmatrani istorijski, oduvek je igrala vodeću ulogu u održanju egzistencije stanovništva. Stočarstvo pruža neophodne proizvode (mleko, meso, jaja), a takođe obezbeđuje sirovine za prehrambenu industriju i industriju kože. Od stočarske proizvodnje se takođe očekuje da obezbedi kvalitetne proizvode za izvoz, pre svega govedine i jagnjetine. Priliku za izvoz imaju sir (posebno od ovčijeg i kozjeg mleka), sa definisanim poreklom i standardom kvaliteta. Međutim, na osnovu raspoloživih podataka, situacija u stočarstvu se ocenjuje kao negativana. U poslednjih nekoliko godina broj grla svih vrsta domaćih životinja kontinuirano se smanjuje. Srbija je dobila kandidaturu za članstvo u Evropskoj uniji (EU). To znači da bi stočarska proizvodnja trebala da se pripremi za konkurenciju na jedinstvenom razvijenom tržištu, bez ikakvih državnih trgovinskih barijera. Članstvo Srbije u međunarodnim organizacijama, liberalizacija trgovine stočarskih proizvoda, mala mogućnost zaštite od uvoza, implementacija standarda kvaliteta (HACCP, ISO, GLOBAL GAP), smanjeni nivo domaće podrške, eliminisanje izvoznih subvencija,rast profitabilnosti i sposobnost da budu konkurentna na međunarodnom tržištu, su još dodatni izazovi sa kojima se suočava ili će se suočiti stočarstvo Srbije. Na osnovu ovih okolnosti, neophodno je da se izgrade principi za efikasan razvoj stočarske proizvodnje, koja može da se takmiči na evropskom tržištu i doprinosi rastu poljoprivrede i nacionalnog dohotka.

\section{References}

ALEKSIC S, PETROVIC, M.M., SRETENOVIC LJ., PANTELIC V., TOMASEVIC D. (2007): Cattle production - current situation and future direction in Republic of Serbia. Biotechnology in Animal Husbandry, Book 1, 23, 5-6, 1-11. BOGDANOVIC, V., DJEDOVIC, R., PERISIC, P., PETROVIC, M. M (2005): Cattle breeding goals and programs in Serbia. Biotechnology in Animal Husbandry 21(5-6, Book 1): 15-21. 
IVANOVIC L., JELOCNIK M., BEKIC B (2009): Possibilities for increment of livestock breeding on the territory of Belgrade city. 113 the EAAE Seminar, Belgrade, Republic of Serbia December 9-11, 2009.

PETROVIC, M., BOGDANOVIC, V., PETROVIC, M.P., RUZIC-MUSLIC, D., OSTOJIC, D (2002): Possibility of improvement of livestock production in hillymountainous region of Serbia. Biotechnology in Animal Husbandry 18(5-6): 1-8.

PETROVIC M, D. RADOJKOVIC, M.MIJATOVIC (2005): Current condition in pig production and potentials for development. Biotechnology in Animal Husbandry, 21. 159-169.

PETROVIC P.M (2007): Sustainable sheep breeding. Institute for Animal Husbandry, Belgrade, $256 \mathrm{pp}$.

PETROVIC P.M, SRETENOVIĆ LJ, RUŽIĆ MUSLIĆ D, MEKIĆ C, MAKSIMOVIĆ N (2009): The effect of the level of application of selection and breeding criteria factor of sustainable sheep production on productive traits of sheep in extensive rearing system. Biotechnology in Animal Husbandry, Vol. 25.12,111-119.

PETROVIĆ M. M., PETROVIĆ M. P., M. PETROVIĆ, S. ALEKSIĆ, D. D. OSTOJIĆ-ANDRIĆ, V. PANTELIĆ, Ž. NOVAKOVIĆ (2011): How to increase production of beef, lamb and pork in Serbia for domestic market and export. $3 \mathrm{rd}$ International Congress-New Perspectives and Challenges of Sustainable Livestock Production, Belgrade, October 5-7. Biotechnology in Animal Husbandry, 27, 293303.

PETROVIĆ M. P., PETROVIĆ M. M., RUŽIĆ-MUSLIĆ D., CARO-PETROVIĆ V., MAKSIMOVIĆ N., ILIĆ Z.,. VUČKOVIĆ S (2011): Opportunities and challenges for sustainable sheep production in Serbia.3 rd International CongressNew Perspectives and Challenges of Sustainable Livestock Production, Belgrade, October 5-7. Biotechnology in Animal Husbandry, 27, 1001-1007.

PETROVIĆ M. P., SRETENOVIĆ LJ, RUŽIĆ-MUSLIĆ D., PACINOVSKI N, MAKSIMOVIĆ N (2011): The effect of crossbreeding systems on lamb meat production. Macedonian Journal of Animal Science, Vol. 1, No. 1, pp. 57-60.

Statistical Yearbooks of Serbia, 1990-2012. Statistical Office of Serbia, Belgrade. 